\title{
Assessing ICT Competencies among Postgraduate Students Based on the 21 st Century ICT Competency Model
}

\author{
Mazalah Ahmad ${ }^{1}$, Aidah Abdul Karim ${ }^{1}$, Rosseni Din $^{1} \&$ Intan Safinas Mohd Ariff Albakri ${ }^{2}$ \\ ${ }^{1}$ Universiti Kebangsaan Malaysia, Selangor, Malaysia \\ ${ }^{2}$ Universiti Pendidikan Sultan Idris, Tanjung Malim, Perak \\ Correspondence: Mazalah Ahmad, Department of Innovation in Teaching and Learning, Faculty of Education, \\ Universiti Kebangsaan Malaysia, 43600 UKM Bangi, Selangor, Malaysia. Tel: 60-3-8921-6054. E-mail: \\ mazalahahmad@yahoo.com
}

Received: August 16, 2013 Accepted: October 14, 2013 Online Published: November 28, 2013

doi:10.5539/ass.v9n16p32 URL: http://dx.doi.org/10.5539/ass.v9n16p32

\begin{abstract}
Assessing the ICT competency among Postgraduate students in the Higher Learning Institutions (HLI) is crucial. Therefore this paper presents in detail the process of developing an instrument to assess the competency in ICT which is called ICTC-Test (Information Communication Technology Competency Test). The details are on the utilization of the seven domains in the 21st Century ICT Competency Model to determine the competency level among students. The development of the items in ICTC-Test is based on the application of the performance-based assessment and the task-based assessment. The assessment of ICT competency using ICTC-Test is different compared to existing instruments where ICTC-Test changes the focus in assessing the competency in ICT from the ability to use and maintain the hardware, software and network to competency in ICT that includes technical ability and cognitive skills. Moreover, ICTC-Test also integrates the five generic skills highlighted in MQF which are critical thinking skill, problem solving skill, information technology and communication skill, communication and management skill.
\end{abstract}

Keywords: ICT competency, assessment in ICT competency, ICT assessment instruments, 21st Century ICT Competency Model, performance-based assessment, task-based assessment

\section{Introduction}

The exposure on the use of technology from as early as in primary school has enabled students to integrate computer technology in their life in the early stage of their lives (Wilkinson, 2006). With the facilities provided, these students can be considered to be 'ICT literate' because they have the opportunities to further integrate computer technology in their lives even after leaving school (Wilkinson, 2006). Therefore, most students who have entered higher learning institutions now are more exposed to ICT compared to the generations before them (McLennan, 2008; Hardy et al., 2006). With the existing knowledge that they have, these students believe that they have sufficient competency to deal with the learning environment in campus (Grant et al., 2009; Wilkinson, 2006; Easton et al., 2006). Students think that they are skilled users of the internet because they use the internet every day (Katz \& Macklin, 2006). This belief made them become less interested to learn the skills in searching for information using search engines and electronic databases. Secondly, even though various efforts have been made to provide exposure to ICT among students as early as in primary school, the ICT gap still exists among students in terms of readiness to accept ICT, and its use and access to the internet (Robiah et al., 2003). Thirdly, without effective assessment, it is difficult to identify if the ICT in education program is beneficial to students and whether the students' competency in ICT has improved through the courses offered. In fact, the main challenge in planning and executing the ICT in education program lies in the development of valid and reliable assessments. Without effective assessments, it is difficult to identify the effectiveness of the program in increasing ICT competency among students (Katz, 2007).

\subsection{The Need for ICT Assessment among Postgraduate Students}

Assessment is important to obtain information on the students' current competency, and this indirectly explains the ICT application programs that have been implemented at all levels. According to Smith and Kirsch (2004), the two main aims in assessing ICT competency are (i) to produce information that would illustrate the 
performance of a particular group and (ii) to explain individual achievements that could be used to validate the ICT competency level of a student. The assessment of individual ICT competency is very much in need and it will be very crucial in understanding the gap in ICT literacy (Smith \& Kirsch, 2004). Individualized data will enable graduates to use the assessment result to help them in deciding the courses that they should take or to determine the best ways to equip themselves in entering certain specializations. The graduates can use the assessment outcomes to identify the career that fits their aptitude, or to inform their potential employers of their abilities. Assessments allow us to determine how far a group of students has obtained the competency needed to enable them to be productive members in the information-rich and technology-based society. Assessment in ICT competency let the faculties and the university administrators decide and explain the strengths and weaknesses in ICT competency of all students or a particular group that is defined based on race, year of study, specialization and other characteristics.

Besides that, the information gained from the assessment can also be used in various other ways including planning courses to eliminate the gap between current competency and the competency required, informing source allocation decisions, curriculum planning, giving accreditation evidence, and assessing the readiness of the instructors, students or for training needs and policy making (Smith \& Kirsch, 2004). The faculties and the administrators, particularly, require assessment data, to measure the effectiveness of current teaching strategies and curriculum, to identify the good practices and to develop a better approach. Complete competency data from assessments will enable administrators of higher learning institutions to evaluate and increase the efforts to ensure that all students obtain required competency in ICT after they have graduated.

\subsection{1 st Century ICT Competency Model}

Nowadays, an effective use of ICT requires cognitive skills and technical skills (ETS, 2002). For that reason, assessment in ICT competency does not only focus on the assessment of technical skills which involves hardware, software and networks, but assessment in ICT competency needs to take into consideration the cognitive skills in order to manage, integrate and assess information (ETS, 2002).

Cognitive skills are needed to balance the rapid changes in technology so that the sophisticated technology can benefit all aspects of life (ETS, 2002). For example, when a student is asked to prepare an electronic presentation based on the information from the World Wide Web, the student can find a huge amount of information with the help of a search engine. The search engine can access the information easier. But to get hold of meaningful information by using the search engine will require cognitive skills. Evaluating and synthesizing information found from various sources also require a higher level of cognitive skills. Cognitive skills, which is how a student think, solve problems and learn, give a larger impact on his ability to play a role in a society that is rich with technology, compared to his knowledge about hardware or certain software. A country not only need citizens who are able to get information, but also citizens who are able to analyze and evaluate what is learned to produce a fact-based opinion. Employers on the other hand need workers who are able to solve problems using technological equipments, not those who can only use the keyboard and mouse.

It is believed that the highest level of ICT competency is being able to create changes in innovation and transformation in individuals and the society. For example, to complete an assignment successfully, such as identifying the best treatment for a particular disease, the individual will need the ability to access information from the internet (technical) and evaluate, apply and integrate information obtained to identify the best treatment method. The cognitive skills and the technical skills have domains that are different and independent, but they are interrelated and they interact to influence the competency in ICT (ETS, 2002). This is explained in Table 1 as follows:

Table 1. Interactions between cognitive skills and technical skills

\begin{tabular}{lcc}
\hline & Low technical skills & High technical skills \\
\hline High cognitive skills & A & B \\
Low cognitive skills & C & D \\
\hline
\end{tabular}

As shown in Table 1, students in Category D have a low cognitive level, but they have high technical skills and are able to carry out technical tasks successfully after receiving training. However students in this category do not have the skills and knowledge to match their ability with new software packages or new hardware or perform new technical tasks. There is a possibility that the students are not able to acquire the technical skills on their 
own. Students in Category A have high cognitive skills but low technical skills, requiring technical trainings (or perhaps motivation or trainings) to increase their competency in ICT, but as soon as they are involved in using ICT, they are able to learn a set of skills and new knowledge quickly independently. The assessment in this form will give detailed information on students' ability and clarify the aspects of the students' weaknesses that need to be addressed.

\section{Objective}

The objective of this research was to develop an instrument to assess competency in ICT which was known as ICTC-Test (Information Communication Technology Competency Test). ICTC-Test was developed based on the 21 st Century ICT Competency Model so that it is able to give information on students' ICT competency which is in accordance with the ICT requirements in the $21^{\text {st }}$ century, and at the same time integrates several generic skills outlined by the Malaysian Qualification Framework: MQF.

\section{Methodology}

This research combined two research methods, namely the qualitative research method and the quantitative research method. The qualitative research methods were used to determine and validate constructs that determine students' ICT competency. The qualitative data were collected using document reviews and through interviews with experts. On the other hand, quantitative research methods were used to get empirical data to find out the quality of items in the ICTC-Test and to determine the validity and reliability of the ICTC-Test. In this research, the qualitative and quantitative approaches were organized and integrated into three phases which were the Planning Phase, Constructing Phase and Instrument Validating Phase (Cohen \& Swerdlik, 2010).

\section{Findings}

ICTC-Test was developed to measure students' ICT competency based on the seven domains found in the $21^{\text {st }}$ Century ICT Competency Model, and the domains are define, access, evaluate, manage, integrate, construct and communicate. ICTC-Test applies the performance-based assessment approach. Then the items in ICTC-Test were developed using the task-based assessment approach. This test contained practical tasks that students have to do individually. The tasks in the ICTC-Test were presented in the form of scenarios of problems that students have to solve. These tasks were designed in order to encourage the students to use their cognitive skills and technical skills to solve the tasks given. An example of the task in the ICTC-Test was shown in Figure 1 as follows: 


\section{$\underline{\text { TASK } 2}$}

\section{SCENARIO:}

On 12 March 2011, a tsunami occurred in Japan. Tsunamis have also hit Mentawai, Indonesia in 2010 and a few states in Malaysia in 2004. The disaster has claimed many lives and destroyed properties. Your lecturer wants you to get as many information as possible on the tsunami that has hit Malaysia and then present the information that you have found in class.

\section{STEPS:}

(You are advised to read all the steps before executing them. Allocation of time suggested for this section is 20 minutes)

a) By using a search engine, find the information required by your lecturer. Please state the search engine and the keywords that you use to find the information needed.

Search engine

$\underline{\text { Keywords }}$

i.

ii.

b) Keep all the information obtained in a subfolder named TSUNAMI in your work folder.

c) Read the materials that you have found and record the information that you feel is important to be presented.

d) Develop a presentation (about 5 minutes) based on the information that you have found from your search.

e) Your presentation should also contain:

i. Links to THREE websites that contain information on tsunami in Malaysia.

ii. Video links on the disaster itself.

f) Keep your presentation files in the TSUNAMI subfolder.

g) E-mail your presentation file to your lecturer (pensyarah2011@yahoo.com) with TWO journal articles on tsunami in 2004. Please include information about yourself (name and registration number) in the e-mail for your lecturer's reference.

Figure 1. Example of a task in ICTC-Test

Task 2 in Figure 1 tested the students' cognitive skills to (i) determine the right keywords to get the necessary information, (ii) assess whether the information resources meet the specified topic in the assignment, and (iii) integrate all sources of information obtained to form a presentation. Task 2 also tested aspects of students' technical skills in terms of their ability to (i) use the right search engine to obtain information, (ii) use electronic presentation software to build a presentation, (iii) save the file with the appropriate name and in an appropriate location, and (iv) write and send e-mails as required in the assignment.

ICTC-Test consisted of eight tasks comprising of 101 items and was categorized into seven domains of ICT competencies that were to define, access, evaluate, manage, integrate, develop and communicate. Overall, the define domain was measured by 46 items, access domain was measured by 15 items, assess a student's ability was determined by 6 items, managerial abilities were determined by 9 items, the ability to integrate was measured by 12 items, while building capacity was measured by 9 items and the students' ability to communicate was determined by 4 items. Details on the distribution of the items were shown in Table 2. 
Table 2. Specifications of ICT competency test

\begin{tabular}{|c|c|c|}
\hline Domain & $\begin{array}{l}\text { No. } \\
\text { of } \\
\text { Item }\end{array}$ & Examples of questions (refer Task 2) \\
\hline Define & 46 & $\begin{array}{l}\text { a) Please indicate the search engines and keywords that you use to get the } \\
\text { information needed. }\end{array}$ \\
\hline Access & 15 & a) By using the search engine, get the information requested by your lecturer. \\
\hline Evaluate & 6 & $\begin{array}{l}\text { c) Read the material that you obtained and note down the information that you feel } \\
\text { important for presentation. }\end{array}$ \\
\hline Manage & 9 & $\begin{array}{l}\text { b) Keep all the information you obtained in a sub-folder named TSUNAMI within } \\
\text { your work folder. }\end{array}$ \\
\hline Integrate & 12 & $\begin{array}{l}\text { d) Create a presentation (approximately } 5 \text { minutes) based on the information you } \\
\text { obtain from your search engine. }\end{array}$ \\
\hline Develop & 9 & $\begin{array}{l}\text { Your presentation should also include: } \\
\text { i. Link to THREE websites that contain information about the tsunami in Malaysia. } \\
\text { ii. Link of video on the disaster. }\end{array}$ \\
\hline Communicate & 4 & $\begin{array}{l}\text { g) E-mail the presentation files to your lecturer (pensyarah2011@yahoo.com) } \\
\text { together with TWO journal articles related to the tsunami disaster in 2004. Your } \\
\text { personal information such as name and registration number should be included with the } \\
\text { e-mail for your lecturer's reference. }\end{array}$ \\
\hline Total & 101 & \\
\hline
\end{tabular}

\section{Discussion}

This research developed a competency assessment instrument named the ICTC-Test. The ICTC-Test was used to determine the students' ICT competency based on the domains found in the $21^{\text {st }}$ Century ICT Competency Model. The ICT competency approaches and assessment techniques in ICTC-Test were designed to meet the needs of generic skills outlined in MQF. Thus, the performance-based assessment approach was applied in the construction of ICTC-Test. The assessment principles were translated through performance-based assessment items in the ICTC-Test which was developed using the task based assessment techniques (task-based assessment).

\subsection{Integration of 21 st Century ICT Competency Model and MQF in ICTC-Test}

ICTC-Test was developed based on the 21st Century ICT Competency Model (Katz \& Macklin, 2006). This model integrated cognitive skills and technical skills through the constructs define, access, evaluate, manage, integrate, develop and communicate to measure the students' ICT competency. ICTC-Test measures the seven domains of ICT competency by integrating ICT components such as the use of word processing, electronic presentations, electronic spreadsheets, electronic databases, and the Internet, e-mails and search engines in the assignments constructed to develop the ICT competency assessment instruments.

The ICTC Test construction not only ensured that the students have ICT competencies to meet the future needs but it also supported the policies outlined by MQF. The ICTC-Test was hoped to be able to test the learning outcomes in the field of ICT which were of knowledge and practical skills as emphasized by MQF (Sharifah Hapsah, 2006). ICTC-Test was also able to measure students' ability to construct generic skills outlined by MQF namely critical thinking skills, problem solving skills, communication skills and information technology and communications skills and management skills. Clearly, ICT competency assessment using the ICTC-Test has changed the focus of ICT competency from the ability to use and maintain the hardware, software and networking to ICT competency which includes the technical skills and cognitive skills. Furthermore, ICTC-Test also integrates the five components of the generic skills highlighted in MQF through the seven domains of ICT Competency Model.

\subsection{Application of Performance-Based Assessment Approach in ICTC-Test}

The development process of ICTC-Test was performed in accordance with the performance approach or also known as performance-based assessment (McMillan, 2007). According to Mohamad Sahari (2002), 
performance-based assessment was able to evaluate the results of a complex and comprehensive learning where it cannot be done by other methods of assessment. The performance-based assessment emphasized the students' ability to perform tasks using their knowledge and skills (McMillan, 2007). According to Nitko (2001), the performance assessment was able to achieve complex learning goals, assess the ability 'to make', in which this approach will enable students to solve problems in real life. Performance-based assessment approach was the best approach for ICTC-Test because it creates useful information on what students can do (Brand 1997). Thus, assessment can be more consistent with modern learning theory that required student to participate actively. Consequently, this approach was suitable in measuring the students' ability in using ICT applications to solve a given problem that relates to everyday life problems.

The performance-based assessment can integrate knowledge and skills in problem-solving activities. Thus, the assessment can be extended to the assessment process and procedures on task than simply evaluating the final product. Assessment processes and procedures in doing work reveal the strengths and weaknesses of the students (Nitko 2001). By using the performance-based assessment approach, this research was able to detect the students' strengths and weaknesses in defining the problems stated in the assignment. Besides that, this approach is able to explore how students interpret, evaluate and integrate information obtained to solve problems, access information, develop products and communicate using ICT applications.

The performance-based assessment produces information that can be used as a basis to predict the student's future ability. According to Gardner (1997), when the assessment takes place in the real context of usage, it is easier to anticipate future achievement.. Thus, ICTC-Test was developed following the principle of performance-based assessment so that the data produced can help researchers and other interested parties to predict the students' ability to apply their ICT skills in everyday life as well as in the working field, as according to Mohd Sallehudin (2002), the results for the performance reference test can be used to predict the candidate's ability of showing similar performance in the future.

\subsection{Application of Task-Based Assessment Techniques in ICTC-Test}

The performance assessment has many forms and methods of gaining students' answers. They include individual or group assignments or both using paper, pencils or materials and resources beyond paper and pencil. According to Nitko (2003), performance assessment requires two main components, namely (1) the tasks and (2) a clear scoring rubric. The task within the performance assessment requires students to demonstrate their achievement through the production of an answer in writing, verbally or through the creation of a specific product.

Since the ICTC-Test was constructed using the performance assessment approach, the students' ICT competency was measured by the students' ability to perform specified tasks. This technique was named as task-based assessment. In this study, the tasks were presented in the form of problem scenarios which need to be solved. Students' competency was determined based on their ability to define the problem that needs to be solved, access the information needed to solve problems in assignments, evaluate and integrate information to solve problems in assignments, develop products in line with the requirements of the assignments as well as to manage and communicate by storing and distributing the outcome of the assignment.

The ICT competency measured by ICTC-Test was different from the existing measurements in several ways. Task-based assessment technique provided more information on students' competency than multiple-choice items. The items of work scenarios were capable of measuring high-level critical thinking and problem solving skills as well as the students' ability to use ICT skills in performing tasks. Task based assessment involved students directly in the performance of assigned tasks. The assignment's scenario explained the tasks that need to be implemented and developed related to teaching and learning activities, jobs and everyday life. To complete the given task, a student must define the problem presented in the scenarios, access information from a variety of digital resources, evaluate the information, manage information obtained or developed, integrate all the information obtained to construct new information, build certain products to display information generated and communicate to disseminate new information produced. Testing session using ICTC-Test required students to use cognitive skills and technical skills to ensure the successful implementation of tasks.

\section{Conclusion}

The research of ICT competency assessment among the students was needed to obtain detailed and accurate information relating to the ability of the students in using ICT in every aspects of life. ICT Competency Test or ICTC-Test (Information Communication Technology Competency Test) was an ICT competency assessment instrument which was built on the principles of performance-based assessment approach. Task based assessment was used as an assessment strategy in ICTC-Test to assess students' competency in using ICT applications and their ability to apply their ICT competency in solving problems related to ICT. The ICTC-Test focused on the 
assessment of students' cognitive abilities and technical capabilities through the seven domains namely to define, access, evaluate, manage, integrate, build and communicate which is distinctive from other instruments.

The assessment using ICTC-Test focused on problem-solving and critical thinking skills related to the use of technology in order to manage the information. The development of ICTC-Test was based on the fact that one's cognitive skills (how they think, solve problems, and learn) have a greater impact on the person's ability to function in a technologically rich society than just being knowledgeable about specific software packages or hardware.

Even though the ICT competency assessment using ICTC-Test required a longer time to be administered and analyzed instead of using multiple-choice items, but the performance assessment meets our higher education's vision to produce graduates who have the skills to think and are skilful in searching for knowledge (Zaini Ujang , 2009). The society needs a person who is not only capable of obtaining information, whether through technology or other means, but who can analyze and evaluate what they have learned in order to develop a thoughtful opinion. Employers' nowadays want to employ staffs who are able to use technology to solve problems, not just those who can type on the keyboard or use the mouse (Smith \& Kirsch, 2004).

\section{References}

Autor, D. H., Levy, F., \& Murnane, R. J. (2003). The Sikll Content on Recent Technological Change: An Emperical Exploration. Quarterly Journal of Economic, 118(4), 127-1334. http://dx.doi.org/10.1162/003355303322552801

Brand, R. (1997). Teaching for Authentic Student Performance Perspectives: On Authentic Performance Assessment. Alexandria, VA: Association for Supervision and Curriculum Development.

Easton, A. C., Easton, G., \& Addo, T. (2006). But I Am Computer Literate: I Passed The Test. Journal of College Teaching \& Learning, 3(2), 39-44.

ETS (Educational Testing Service). (2002). Digital Transformation: A Framework for ICT Literacy. A Report of the International ICT Literacy Panel, Educational Testing Service. Princeton, NJ. Akses pada: 14 November 2008.

Gardner, H. (1997). Assessment in context: The alternative to standardized testing. Dlm. Ibrahim bin Mohamed Zin (2007), Membina dan Mengesahkan Instrumen Pentaksiran Kecerdasan Pelbagai. Doktor Falsafah. Universiti Kebangsaan Malaysia. Bangi.

Grant, M. D., Malloy, A. D., \& Murphy, M. C. (2009). A Comparison of Student Perceptions of Their Computer Skills to Their Actual Abilities. Journal of Information Technology Education, 8, 141-160.

Hardy, C., Heeler, P., \& Brooks, D. (2006). Are High School Graduates Technologically Ready for Post-Secondary Education? Journal of Computing Sciences in Colleges, 21(4), 52-60.

Kasa, Z., Yunus, A. S. M., Asmuni, A., Napis, S., Samah, B. A., Yusoff, M. Z. M., ... Ismail, S. M. N. S. (2005). Kesediaan Pelajar Institute Pengajian Tinggi Menggunakan Komputer Dalam Pembelajaran. Jurnal pendidikan Universiti Malaya, 133-142.

Katz, I. R. (2007). Testing information literacy in digital environments: The ETS iskills ${ }^{\mathrm{TM}}$ assessment. Information Technology and Libraries, 26(3).

Katz, I. R., \& Macklin, A. S. (2006). Information and Communication Technology (ICT) Literacy: Integration and Assessment in Higher Education. Systemics, Cybernetics and Informatics, 5(4), 50-55.

Katz, I. R., Williamson, D. M., Nadelman, H. L., Kirsch, I., Almond, R. G., \& Cooper, P. L. (2004). Assessing Information and Communications Technology Literacy for Higher Education. In Paper presented at the 30th annual conference of the International Association for Educational Assessment.

KPT (Kementerian Pengajian Tinggi). (2007). Pelan Strategik Pengajian Tinggi Negara Melangkau Tahun 2020. Kuala Lumpur: Kerajaan Malaysia.

Lin, H. C. (2000). Make IT Happen in Your Syllabus. Dlm. Nik Hairi Omar, Mohd Azul Mohd Salleh \& Norizan Abdul Razak (2006). Pentaksiran Kecekapan Teknologi Komunikasi Maklumat (TKM) Dalam Kalangan Pelajar Sains Sosial. Jurnal Pendidikan Universiti Malaya.

Mc Millan, J. H. (2007). Classroom Assessment: Principal and Practice for Effective Standard-Base Instruction (4th ed.). USA: Pearson Education, Inc.

McLennan, T., \& Gibbs, S. (2008). Has The Computing Competence of First Year University Students Increased 
During The Last Decade? Proceeding Ascilite Mekbourne 2008.

Nitko, A. J. (2001). Educational Assessment of Students (3rd ed.). New Jersey: Prentice Hall.

Nitko, A. J. (2003). Alternative Assessment in Teaching and Learning. Ucap Utama Dalam $2^{\text {nd }}$ International Conference on Measurement and Evalution in Education. Pulau Pinang. 27-30 Ogos.

Nordin, M. S. (2002). Pengujian Dan Penaksiran Di Bilik Darjah. Kuala Lumpur: Pusat Penyelidikan, Universiti Islam Antarabangsa.

Sallehudin, M. (2002). Validating A Domain Referenced Testing Using Quantitative And Qualitative Measures. Prosiding $2^{\text {nd }}$ International Conference on Measurement and Evalution in Education. Pulau Pinang. 27-30 Ogos.

Shahabudin, S. H. S. H. (2006). Kerangka Kelayakan Malaysia. Lembaga Akreditasi Negara.

Sidin, R., Salim, J., \& Mohamed, N. S. (2003). Pembudayaan Teknologi Maklumat dan Komunikasi di Kalangan Pelajar Melayu dalam Arus Globalisasi. Laporan Akhir Penyelidikan Arus Perdana II. Bangi: Penerbit Universiti Kebangsaan Malaysia,

Smith, G., \& Kirsch, I. (2004). Innovative Assessment of ICT Literacy. In J. Nall, \& R. Robson (Eds.), Proceedings of World Conference on E-Learning in Corporate, Government, Healthcare, and Higher Education 2004 (pp. 443-448). Chesapeake, VA: AACE.

Ujang, Z. (2009). Mengangkasa Pengajian Tinggi: Masa Hadapan - Menjangkau Bintang Meraih Mercu. Kertas kerja. Seminar Percambahan Pemikiran Islam: Dimensi 7 Prinsip Universiti APEX. 9 Jun 2009. Universiti Sains Malaysia. Akses pada 11 Disember 2010 dari. Retrieved from http://www.utm.my/vc-arc/images/syarahan-utama-usm-pengajian\%20tinggi-12jun2009.pdf

Valetta, R. (2004). The Computer Evolution, FRBSF Economic Letter, 42-47. Dlm. Wilkinson, K. (2006). Students Computer Literacy: Perception Versus Reality. Delta Pi Epsilon Journal, 48(2), 108-120.

Wilhelm, A. (2004). Digital Nation. Toward an Inclusive Information Society. Cambridge, MA: MIT Press.

Wilkinson, K. (2006). Students Computer Literacy: Perception Versus Reality. Delta Pi Epsilon Journal, 48(2), 108-120.

Yaakob, M., \& Mamat, M. (2000).Sekolah Bestari: Menangani Pembinaan Budaya Ilmu Berfikir Secara Kritis Dan Kreatif. Dlm. Mohd Azul Mohd Salleh, Norizan Abdul Razak \& Nik Hairi Omar (2005). Pengetahuan dan Kemahiran ICT pelajar: Satu Penilaian.

\section{Copyrights}

Copyright for this article is retained by the author(s), with first publication rights granted to the journal.

This is an open-access article distributed under the terms and conditions of the Creative Commons Attribution license (http://creativecommons.org/licenses/by/3.0/). 